\title{
Pengaruh Kepribadian Hardiness dan Kepemimpinan Transformational terhadap Kinerja Karyawan PDAM Kota Malang
}

\author{
Muslimin \\ Fakultas Psikologi, Universitas Muhammadiyah Malang \\ e-mail: muslimin.ngali@yahoo.com
}

\begin{abstract}
Employee performance is influenced by several factors such as internal factors and external factors. The purpose of this study was to determine the effect of hardiness and transformational leadership on employee performance simultaneously or together. The sampling technique uses simple random sampling in one of the PDAM companies in Malang. Subjects in this study were 150 employees. The data collection method in this study uses a hardiness personality scale, transformational leadership scale and employee performance scale. The results of the analysis of the multiple regression test showed that the hardiness and transformational leadership influences simultaneously or jointly on employee performance with an influence contribution of $49 \%$. While partially transformational leadership has no influence on employee performance.
\end{abstract}

KEYWORDS Hardiness personality, transformational leadership, employee performance

CITATION Muslimin. (2020). Pengaruh kepribadian hardiness dan kepemimpinan transformational terhadap kinerja karyawan pada pdam kota malang. Cognicia, 8, (1), 445-460.

Sumber daya manusia memegang peranan penting dalam suatu perusahaan. Secara umum fungsi sumber daya manusia adalah mengatur dan mengelola karyawan semaksimal dan seefekif mungkin agar diperoleh kinerja yang maksimal. Peran SDM sangat berpengaruh terhadap kinerja karyawan karena karyawan merupakan sumber daya yang paling penting dan sangat menentukan dalam kelangsungan hidup suatu perusahaan. Perusahaan tentunya ingin mendapatkan kinerja karyawan yang optimal dalam setiap bidang masing-masing. Hal itu bisa dilakukan ketika perusahaan mampu melakukan pemeliharaan dan pengelolaan sumber daya manusia. Langkah yang dilakukan untuk mendapatkan kinerja karyawan yang memuaskan antara lain motivasi kerja, lingkungan kerja dan pengaruh kepemimpinan.

Kinerja seseorang merupakan ukuran sejauh mana keberhasilan seseorang dalam melakukan tugas pekerjaannya (Hasibuan, 2016). Kinerja karyawan sering diartikan sebagai pencapaian tugas dimana karyawan dalam bekerja harus sesuai dengan program kerja organisasi untuk menunjukkan tingkat kinerja organisasi dalam mencapai visi,s misi dan tujuan organisasi. Kinerja karyawan dapat dijadikan sebagai bahan evaluasi untuk perusahaan. Kinerja memiliki porsi penting dalam organisasi, karena keberhasilan dalam melakukan pekerjaan sangat ditentukan oleh kinerja dan kinerja berkaitan dengan seberapa baik seseorang dalam melakukan tugasnya. Kinerja 
karyawan dipengaruhi oleh tiga faktor menurut Wirawan (2009), pertama faktor internal karyawan, kedua yaitu faktor lingkungan internal organisasi, dan ketiga yaitu faktor eksternal organisasi. Terdapat beberapa penelitian yang telah menunjukkan bahwa pentingnya faktor individu, faktor organisasi dan faktor manajemen. Penelitian yang dilakukan oleh Devita (2017), menunjukkan bahwa faktor-faktor individu, organisasi dan manajemen mempengaruhi kinerja karyawan.

Karyawan harus belajar untuk menyesuaikan diri dengan lingkungan dalam perusahaan. Jika penyesuaian diri berhasil maka seorang karyawan tersebut dapat berinteraksi dengan lebih baik dan menghasilkan kinerja yang tinggi, kepuasan dan tingkat stress yang rendah. Sebaliknya jika karyawan gagal melakukan penyesuaian diri akan berdampak pada interaksi yang tidak harmonis. Hal tersebut dapat menyebabkan kinerja yang buruk, ketidakpuasan dan tingkat stres yang tinggi. Terdapat beberapa penelitian yang telah dilakukan sebelumnya berkaitan dengan kinerja karyawan. Penelitian yang dilakukan oleh Turang (2015), menunjukkan bahwa gaya kepemimpinan, motivasi, dan disiplin kerja memiliki pengaruh positif terhadap kinerja karyawan secara simultan. Gaya kepemimpinan mempengaruhi kinerja karyawan secara parsial. Motivasi mempengaruhi kinerja karyawan secara parsial, dan disiplin kerja mempengaruhi kinerja karyawan. Penelitian Parashakti, Haryadi, \& Nashar (2018), menyatakan bahwa gaya kepemimpinan dan disiplin kerja memiliki pengaruh yang signifikan terhadap kinerja karyawan PT. Telekomunikasi Indonesia, Tbk DKI Jakarta. Selain itu, penelitian Omollo, \& Oloko (2015), menunjukkan bahwa motivasi berpengaruh terhadap kinerja karyawan.

Untuk menciptakan sumber daya manusia yang memiliki kinerja tinggi memang tidak mudah. Berbagai masalah dan kesulitan pada karyawan merupakan tantangan yang harus dihadapi dalam menjalani pekerjaanya. Upaya dalam mengatasi perubahan dan tantangan yang dihadapi karyawan, berkaitan erat dengan hardiness yang harus dimiliki oleh karyawan. Salah satu faktor individu yang dapat mempengaruhi kinerja adalah kepribadian tangguh (hardiness), dimana hardiness merupakan pola sikap dan tindakan yang membantu mengubah kondisi stres menjadi sebuah peluang untuk berkembang. Dodik dan Astuti (2012) menjelaskan bahwa seseorang dengan kepribadian hardiness cenderung memiliki penyesuaian diri yang lebih baik terutama pada saat berada dalam peristiwa dan kondisi yang beresiko menimbulkan stres di tempat kerja.

Hardiness adalah konstruk kepribadian yang terstruktur dan berfungsi sebagai daya tahan ketika individu dihadapkan pada keadaan stres (Kobasa, 1982). Menurut Kobasa individu yang memiliki hardiness tinggi mempunyai serangkaian sikap yang membuat mereka tahan terhadap stres. Individu dengan kepribadian hardiness senang bekerja keras karena dapat menikmati pekerjaan yang dilakukan, senang membuat sesuatu yang harus dimanfaatkan dan diisi agar mempuyai makna dan membuat individu tersebut sangat antusias dalam menyongsong masa depan. Hal tersebut, dikarenakan perubahan-perubahan dalam kehidupan dianggap sebagai tantangan dan sangat berguna untuk perkembangan hidupnya. Lebih lanjut, Kobasa mendefinisikan bahwa hardiness adalah karakteristik kepribadian yang mempunyai fungsi sebagai sumber perlawanan pada saat individu menghadapi stres. 
Hardiness dapat pula diartikan sebagai ketangguhan individu dalam merespon masalah, dimana individu yang menunjukkan hardiness cenderung jarang mengalami stres ketika dihadapkan pada suatu masalah (Jannah, 2018). Di dalam hardiness terdapat 3 komponen yang dikemukakan oleh Kobasa, yakni komitmen, kontrol, dan tantangan (Kalantar, Leyla, Nikbakht, \& Motvalian, 2013). Individu dengan kepribadian hardiness berkomitmen bahwa apapun kegiatan yang mereka lakukan akan memberikan pengaruh pada kehidupan mereka sendiri, serta dapat menjadikan situasi yang sulit menjadi sebuah kesempatan atau peluang untuk dapat tumbuh dan berkembang. Dalam penelitian yang dilakukan oleh Temaja, \& Utama (2016), memperlihatkan bahwa kepribadian hardiness memberikan pengaruh positif pada kinerja auditor.

Menciptakan sumber daya manusia yang memiliki kinerja tinggi bukan hanya dipengaruhi oleh kepribadian hardiness. Dalam mencapai proses ini perlu dukungan dari organisasi. Dukungan organisasi yang dimaksud adalah dukungan dari pemimpin organisasi yang bersangkutan. Hal ini dikarenakan kesuksesan sebuah organisasi dalam mencapai semua rencananya bergantung pada pemimpin yang mengarahkan dan kepada bawahan sebagai yang diarahkan. Pemimpin pada dasarnya memiliki kemampuan untuk mempengaruhi, menggerakkan, dan mengarahkan suatu tindakan pada seseorang atau kelompok untuk tujuan tertentu (Tampi, 2014). Hal tersebut juga dikuatkan dengan pernyataan bahwa gaya kepemimpinan merupakan cara seorang pemimpin mempengaruhi, mengarahkan, memotivasi, dan mengendalikan bawahan dengan cara tertentu, sehingga bawahan dapat menyelesaikan tugas secara efektif dan efisien (Soleha, 2012).

Kepemimpinan transformasional adalah pemimpin yang mampu memberi inspirasi bawahan untuk lebih mengutamakan kemajuan organisasi daripada kepentingan pribadi, memberi perhatian yang baik terhadap bawahan dan mampu merubah kesadaran bawahannya dalam melihat permasalahan lama dengan cara yang baru (Robbin dalam Rokhman dan Harsono, 2002). Kepemimpinan transformasional menurut Nawawi (2003) adalah pendekatan kepemimpinan dengan melakukan usaha untuk mengubah kesadaran membangkitkan semangat dan mengilhami bawahan atau anggota organisasi untuk mengeluarkan usaha ekstra dalam mencapai tujuan organisai, tanpa merasa ditekan atau tertekan. Menurut teori ini kepemimpinan transformasional lebih menekankan pada kegiatan pemberdayaan (empowerment) melalui peningkatan konsep diri bawahan atau anggota yang positif. Para bawahan/anggota organisasi yang memiliki konsepsi positif tersebut, diharapakan mampu mengatasi permasalahan dengan mempergunakan potensinya masing-masing tanpa merasa ditekan atau tertekan sehingga dengan kesadaran sendiri membangun komitmen yang tinggi terhadap pencapaian tujuan organisasi.

Seseorang pemimpin pada hakekatnya dituntut untuk mengetahui apa kebutuhan, keinginan, dan harapan bawahannya dan mempengaruhi bawahannya untuk bertindak sesuai dengan tujuan yang telah ditetapkan. Kepemimpinan transformasional seperti diuraikan di atas sangat positif dilaksanakan dalam kepemimpinan untuk mendorong atau berperan serta menciptakan kondisi organisasi yang mendorong meningkatnya kinerja karyawan. Kepemimpinan merupakan aspek yang paling penting dalam kehidupan organisasi atau perusahaan. Berhasil atau 
tidaknya kegiatan perusahaan sering dikaitkan dengan keberadaan pimpinan dalam perusahaan tersebut, tanpa kepemimpinan yang efektif maka kegiatan perusahaan sulit untuk diarahkan pada pencapaian tujuan yang telah ditetapkan.

Penelitian yang dilakukan oleh Palgunanto, Suparno, \& Dwityanto, (2010), menjelaskan bahwa terdapat hubungan positif yang sangat signifikan antara gaya kepemimpinan transformasional dengan kinerja. Semakin tinggi gaya kepemimpinan transformasional maka semakin tinggi kinerja. Berbeda dengan penelitian yang dilakukan oleh Kharis, (2015), menyatakan bahwa gaya kepemimpinan transformasional berpengaruh tidak langsung terhadap kinerja karyawan. Berdasarkan hasil tersebut, pimpinan bank hendaknya lebih meningkatkan dalam menerapkan gaya kepemimpinan transformasional, dengan memberikan contoh untuk bersikap loyal pada bank dan mendorong karyawan untuk bekerja lebih baik.

Perusahaan Daerah Air Minum (PDAM) adalah suatu perusahaan yang dibentuk oleh Pemerintah Kota Malang sebagai pengelola penyediaan sarana air bersih untuk kebutuhan masyarakat. Penyediaan air bersih merupakan salah satu bentuk penyelenggaraan pelayanan publik yang menjadi tanggung jawab pemerintah daerah, dalam hal ini Pemerintah Kota Malang. Sesuai dengan amanat Undang-Undang No. 23 Tahun 2014 tentang Pemerintah Daerah yang menyatakan bahwa Pemerintah Daerah diberikan kewenangan untuk mengatur dan mengurus kepentingan masyarakat daerahnya sendiri, salah satunya kepentingan air bersih. Untuk menindaklanjuti amanat undang-undang ini maka Pemerintah Kota Malang mendirikan Badan Usaha Milik Daerah (BUMD) yang dikenal dengan nama Perusahaan Daerah Air Minum (PDAM). Permasalahan yang terjadi adalah aliran air yang kecil bahkan mati. Permasalahan kinerja Perusahaan Daerah Air Minum (PDAM) dalam pengelolaan air di Kota Malang ditandai dengan adanya gangguan, seperti air tidak mengalir dan sering terjadi masalah kerusakan/kebocoran pipa. Dari masalah yang telah diuraikan di atas, karyawan PDAM dalam menjalankan beban kerja yang berat tentu mengalami stres ketika bekerja, oleh karenanya kepribadian hardiness dan dukungan dari seorang pemimpin sangat diperlukan agar mampu mengontrol dan mengendalikan stres ketika bekerja, sehingga menghasilkan kinerja yang optimal.

Beberapa permasalahan yang ada cukup menunjukkan bahwa kinerja pelayanan PDAM Kota Malang belum optimal. Sebagai perusahaan pelayanan publik, seharusnya PDAM menempatkan kepentingan pelanggan sebagai hal yang utama. Hal ini sesuai dengan apa yang disampaikan Rangkuti (2013) bahwa perusahaan harus berorientasi pada kepentingan pelanggan dengan memperhatikan komponen kualitas pelayanan. Pelayanan yang berkualitas tentunya akan menghasilkan kepuasan yang dirasakan oleh pelanggan. Pelanggan akan merasa puas apabila harapan yang mereka inginkan dapat dipenuhi oleh PDAM. Untuk mengetahui seperti apa kinerja PDAM yang dirasakan oleh pelanggan maka perlu dilakukan pengukuran kinerja PDAM berdasarkan kepuasan pelanggan. Selama ini pengukuran kinerja terhadap PDAM telah dilakukan berdasarkan standar penilaian oleh pemerintah. Penilaian ini dilakukan terhadap kondisi internal/operasional dari PDAM itu 
sendiri sehingga hasil dari penilaian ini tidak diketahui dan dirasakan masyarakat atau pelanggan secara langsung.

Alasan peneliti mengambil judul ini karena penelitian tentang kepribadian hardiness dan kepemimpinan transformasional terhadap kinerja karyawan sesuai dengan karakteristik yang ada di BUMN dimana BUMN selalu berkomitmen ketika perusahaan dihadapkan dengan masalah dan dapat mengontrol supaya perusahaan tetap berjalan sesuai dengan tujuan serta dapat mengahadapi tantangan sesuai dengan perkembangan zaman. Selain itu penelitian ini sangat membantu perusahaan mengingat beban kerja yang ditanggung karyawan cukup berat dan penelitian ini jarang dilakukan.

Berdasarkan paparan di atas dan penelitian yang dilakukan sebelumnya, maka sangat penting menjadi dasar peneliti untuk mengetahui lebih lanjut tentang bagaimana Pengaruh Kepribadian Hardiness dan Kepemimpinan Transformasional terhadap Kinerja karyawan pada PDAM Kota Malang. Manfaat praktis dari penelitian ini sebagai bahan masukan bagi organisasi agar dapat meningkatkan kualitas dari organisasi. Manfaat praktis bagi peneliti sebagai penerapan ilmu-ilmu psikologi di bidang psikologi industri organisasi dan perusahaan, serta sebagai masukan bagi organisasi maupun perusahaan untuk menjadi lebih baik dari sebelumnya. Manfaat teoritis dari peneitian ini, untuk pengaplikasian ilmu psikologi di bidang psikologi industri organisasi serta menambah kajian teori dibidang psikologi industri organisasi.

\section{METODE}

Rancangan penelitian ini merupakan pedoman dan langkah-langkah yang diikuti oleh peneliti untuk melakukan penelitian. Pendekatan yang digunakan dalam penelitian ini adalah pendekatan kuantitatif. Menurut Azwar (2013), penelitian kuantitatif menekankan analisisnya pada data-data numerical yang diolah dengan metode statistik. Data yang diperoleh dari sampel dan populasi penelitian dianalisis sesuai dengan metode statistik yang digunakan. Dalam penelitian ini dimaksudkan untuk mengetahui berapa besar pengaruh Kepribadian Hardiness dan Transformational Leadership terhadap Kinerja Karyawan yang dilengkapi analisis data sehingga dapat dipahami dan mendapatkan kesimpulan. Penelitian ini menggunakan skala sebagai instrumen pengumpulan data.

Menurut Sugiyono (2011) populasi adalah wilayah generalisasi yang terdiri atas obyek atau subyek yang memiliki kualitas dan karakteristik tertentu yang ditetapkan oleh peneliti kemudian dipelajari dan ditarik kesimpulan. Setelah menentukan populasi, peneliti akan mengambil sampel. Sugiyono (2011) sampel adalah bagian dari jumlah dan karakteristik yang dimiliki oleh populasi. Berdasarkan populasi tersebut, pengambilan sampel dalam penelitian ini menggunakan metode simple random sampling. Menurut Sugiyono (2015) teknik simple random sampling adalah teknik pengambilan sampel dari anggota populasi yang dilakukan secara acak tanpa memperhatikan strata dalam populasi. Subyek dalam penelitian ini sebanyak 150 karyawan yang diambil dari populasi berjumlah 338 karyawan.

Penelitian ini memiliki variabel bebas $(X)$ dan variabel terikat $(Y)$. Variabel bebas (X1) yang digunakan yaitu Kepribadian Hardiness dan (X2) yaitu Kepemimpinan Transformational sedangkan variabel terikat (Y) yang digunakan yaitu Kinerja 
Karyawan. Variabel-variabel tersebut akan diungkap menggunakan kuesioner. Kelebihan dari kuesioner ini adalah akan didapatkan data angka yang akan mempermudah untuk dianalisis melalui prosedur statistik. Variabel bebas adalah variabel yang biasa disebut sebagai variabel pengaruh atau variabel independent. Variabel ini diduga akan memberikan pengaruh terhadap variabel lain yang berada bersamaan dalam suatu waktu. Sedangkan variabel terikat disebut juga sebagai variabel efek atau variabel yang dipengaruhi oleh variabel bebas.

Hardiness dapat diartikan sebagai karakteristik kepribadian yang tangguh pada diri individu dan dapat membantu individu untuk dapat menghadapi kondisi yang tidak menyenangkan atau tidak menguntungkan dengan cara mengubah permasalahan yang sedang dihadapi menjadi sebuah peluang yang positif untuk dapat tumbuh dan berkembang. Skala kepribadian hardiness disusun berdasarkan adaptasi skala OHQ (Occupational Hardiness Questionnaire) yang dibuat oleh Jimenez, Munoz, Hernandez dan Blanco (2014) dengan jumlah 15 aitem, berdasarkan aspek kepribadian hardiness yaitu komitmen, kontrol, dan tantangan.

Kepemimpinan transformational adalah suatu keadaan dimana para pengikut dari seorang pemimpin transformasional merasa adanya kepercayaan, kekaguman, kesetiaan, dan hormat terhadap pemimpin tersebut dan mereka termotivasi untuk melakukan hal-hal yang lebih dari pada sebelumnya. Skala kepemimpinan kepemimpinan transformational disusun berdasarkan adaptasi skala MLQ (Multifactor Leadership Questionnaire) yang dibuat oleh Wildan (2017) dengan jumlah 28 aitem, berdasarkan aspek kepemimpinan transformasional yaitu individualized influence, inspirational motivation, intellectual stimulation dan individual consideration.

Kinerja merupakan gambaran hasil kerja yang dilakukan seseorang. Skala kinerja disusun berdasarkan skala yang dibuat oleh Tentama (2015) dengan jumlah 15 aitem berdasarkan aspek kinerja yaitu quality of work (kualitas kerja), promptness (ketepatan waktu), initiative (inisiatif), capability (kemampuan), dan communication (komunikasi).

Teknik pengumpulan data yang digunakan dari keseluruhan instrument yaitu dengan menggunakan jenis skala Likert yang terdiri dari item favourable dan item unfavourable dengan menggunakan empat pilihan jawaban yaitu sangat setuju (SS), setuju (S), tidak setuju (TS) dan sangat tidak setuju (STS). Secara jelas dirincikan sebagai berikut: sangat setuju pada favorable diberikan nilai 4 dan unfavorable nilai 1 , setuju pada favorable diberikan nilai 3 dan unfavorable nilai 2, tidak setuju pada favorable diberikan nilai 2 dan unfavorable nilai 3, dan sangat tidak setuju pada favorable diberikan nilai 1 dan unfavorable nilai 4.

Tabel 1. Indeks Validitas dan Reliabilitas Alat Ukur Penelitian

\begin{tabular}{lccc}
\hline \multicolumn{1}{c}{ Alat Ukur } & Jumlah Item Valid & Indeks Validitas & Indeks Reliabilitas \\
\hline Hardiness & 14 item & $0,388-0,680$ & 0,889 \\
\hline $\begin{array}{l}\text { Kepemimpinan } \\
\text { Transformational }\end{array}$ & 28 item & $0,222-0,750$ & 0,943 \\
\hline Kinerja & 16 item & $0,414-0,630$ & 0,864 \\
\hline
\end{tabular}


Dari hasil uji validitas dan reliabilitas skala hardiness, kepemimpinan transformational dan kinerja, diketahui skala hardiness terdiri dari 15 aitem terdapat 1 aitem yang tidak valid sehingga tersisa 14 aitem valid yang dapat mengukur hardiness. Indeks validitas skala hardiness berkisar dari 0,388-0,680 dan nilai reliabilitas sebesar 0,889 . Hasil uji validitas dan reliabilitas dari skala kepemimpinan transformational dari 28 aitem tidak terdapat aitem yang gugur. Indeks validitas berkisar dari 0,222-0,750 dan nilai reliabilitas sebesar 0,943. Sedangkan skala kinerja terdiri dari 20 aitem terdapat 4 item yang tidak valid sehingga hanya tersisa 16 aitem valid. Indeks validitas skala kinerja berkisar dari 0,414-0,630 dan nilai reliabilitas sebesar 0,864.

Penelitian yang dilakukan memiliki tiga prosedur utama. Pertama, tahap persiapan, dimulai dari peneliti melakukan pendalaman materi melalui kajian teoritik. Peneliti menyusun dan mengembangkan alat ukur berdasarkan aspek dalam variabel, selanjutnya peneliti meminta ijin untuk melakukan penelitian (pengambilan data). Peneliti menggunakan uji coba atau try out dengan jumlah subyek try out 100 subyek PDAM. Selanjutnya peneliti melakukan analisa data menggunakan (SPSS) 22 untuk mendapatkan aitem valid dan reliabel. Kedua, tahap pelaksanaan peneliti memberikan skala pada karyawan PDAM yang memenuhi persyaratan sesuai dengan karakteristik sampel. Peneliti memberikan tiga skala yaitu, skala kepribadian hardiness, skala kepemimpinan transformational dan skala kinerja karyawan. Ketiga, tahap analisa yaitu menganalisa hasil yang didapatkan dari tiga skala kepada 150 subyek. Data-data yang telah diperoleh kemudian diinput dan diolah menggunakan program perhitungan statistic SPSS 22, yaitu analisis regresi berganda.

\section{HASIL}

Subyek dalam penelitian ini adalah karyawan PDAM Kota Malang. Subyek dalam penelitian ini berjumlah 150 karyawan. Berikut ini data demografis dari subyek penelitian:

Tabel 2. Deskripsi Subyek Penelitian

\begin{tabular}{lcc}
\hline \multicolumn{1}{c}{ Kategori } & Frekuensi & Presentase \\
\hline Jenis Kelamin & & \\
Laki-Laki & 87 & $58 \%$ \\
Perempuan & 63 & $42 \%$ \\
\hline Usia & & \\
$20-30$ & 46 & $31 \%$ \\
$31-40$ & 44 & $29 \%$ \\
$41-50$ & 37 & $25 \%$ \\
$51-60$ & 23 & $15 \%$ \\
\hline Lama Bekerja & & \\
$0-5$ Tahun & 49 & $33 \%$ \\
5-10 Tahun & 38 & $25 \%$ \\
10-20 Tahun & 12 & $8 \%$ \\
20-30 Tahun & 51 & $34 \%$ \\
\hline Pendidikan & & \\
\hline
\end{tabular}




\begin{tabular}{lcc}
\hline SMA & 14 & $9 \%$ \\
SLTA & 3 & $2 \%$ \\
SMK & 1 & $1 \%$ \\
SMU & 4 & $4 \%$ \\
D3 & 4 & $4 \%$ \\
S1 & 121 & $81 \%$ \\
S2 & 3 & $2 \%$ \\
\hline
\end{tabular}

Dari tabel di atas diketahui bahwa jumlah subyek sebanyak 150, subyek dalam penelitian ini didominasi oleh karyawan yang berjenis kelamin laki-laki sejumlah 87 orang dengan presentase 58\%, sisanya adalah karyawan yang berjenis kelamin perempuan sebanyak 63 orang dengan presentase $42 \%$. Selanjutnya dari jumlah usia diketahui bahwa karyawan yang berumur antara 20-30 tahun berjumlah 46 orang dengan presentase $31 \%$, 31-40 tahun berjumlah 44 orang dengan presentase $29 \%$, 41-50 tahun berjumlah 37 orang dengan presentase 25\%, dan 51-60 tahun berjumlah 23 orang dengan presentase 15\%. Ditinjau dari lama bekerja karyawan yang sudah bekerja antara 0-5 tahun sebanyak 49 orang dengan presentase 33\%, 5-10 tahun sebanyak 38 orang dengan presentase $25 \%, 10-20$ tahun sebanyak 12 orang dengan presentase $8 \%$, 20-30 tahun sebanyak 51 orang dengan presentase 34\%. Sedangkan dilihat dari pendidikan SMA sebanyak 14 orang dengan presentase 9\%, SLTA sebanyak 3 orang dengan presentase $2 \%$, SMK sebanyak 1 orang dengan presentase $1 \%$, SMU sebanyak 4 orang dengan presentase $4 \%$, D3 sebanyak 4 orang dengan presentase $3 \%$, S1 sebanyak 121 dengan presentase $81 \%$, dan S2 sebanyak 3 orang dengan presentase $2 \%$.

Berdasarkan uji Kolmogorov-smirnov, suatu data dapat dikatakan normal jika nilai signifikan di atas 0,05. Dari hasil uji normalitas yang sudah dilakukan pada kedua variabel dikatakan normal karena nila signifikan sebesar 0,200 atau lebih besar dari $>0,05$. Selanjutnya uji heteroskedastisitas, berdasarkan uji heteroskedastisitas diketahui nilai signifikan variabel hardiness adalah sebesar 0,000 dengan demikain dapat disimpulkan bahwa nilai signifikan untuk variabel tersebut lebih kecil dari 0,05, artinya terjadi heteroskedastisitas dalam model regresi pada penelitian ini. Sedangkan pada variabel kepemimpinan transformational sebesar 0,967, dengan demikian dapat disimpulkan bahwa nilai signifikan untuk varibel ini lebih besar dari 0,05, artinya tidak terjadi heteroskedastisitas dalam model regresi pada penelitian ini.

Selanjutnya skor dari variabel hardiness (X1), kepemimpinan transformational (X2), dan kinerja karyawan (Y) berdasarkan kategori tinggi dan rendah. Cara menentukan kategorisasi adalah dengan menentukan nilai minimal (nilai terendah) dan maksimal (nilai tertinggi) terlebih dahulu dari masing-masing variabel, langkah selanjutnya adalah menentukan nilai interval dengan cara, nilai tertinggi dikurangi nilai terendah dari masing-masing variabel. Berikut adalah tabel kategorisasi dari masing-masing variabel:

Tabel 3. Gambaran/Kategorisasi Variabel Penelitian

\begin{tabular}{llllll} 
Variabel & N & Tinggi & Presentase & Rendah & Presentase \\
\hline
\end{tabular}




\begin{tabular}{lccccc}
\hline Hardiness & & 70 & $47 \%$ & 80 & $53 \%$ \\
\cline { 3 - 6 } $\begin{array}{l}\text { Kepemimpinan } \\
\text { Transformational }\end{array}$ & \multirow{2}{*}{150} & 68 & $45 \%$ & 82 & $55 \%$ \\
\hline Kinerja & & 42 & $28 \%$ & 108 & $72 \%$ \\
\cline { 2 - 6 } & & & &
\end{tabular}

Berdasarkan tabel di atas diketahui bahwa subyek yang memiliki kepribadian hardiness tinggi adalah sebanyak 70 orang karyawan dengan presentase $47 \%$, dan nilai terendah yaitu 80 orang dengan presentase 53\%. Selanjutnya dari variabel kepemimpinan transformational diketahui subyek yang memiliki nilai tertinggi yakni sebesar 68 orang karyawan dengan presentase $45 \%$ dan nilai terendah sebanyak 82 orang karyawan dengan presentase 55\%. Sedangkan variabel kinerja yang mendapatkan nilai tertinggi adalah sebesar 42 karyawan dengan presentase $28 \%$ dan nilai terendah sebanyak 108 orang karyawan dengan presentase $72 \%$.

Selanjutnya untuk mengetahui adanya pengaruh kepribadian hardiness dan transformational leadership terhadap kinerja PDAM secara simultan atau secara bersama-sama, maka peneliti melakukan analisis dengan menggunakan teknik regresi berganda. Berikut hasil uji regresi berganda yang diperoleh dengan cara membandingkan nilai $\mathrm{F}$ hitung dengan $\mathrm{F}$ tabel dengan ketentuan $\mathrm{F}$ hitung harus lebih besar dari nilai $\mathrm{F}$ tabel.

Tabel 4. Uji korelasi Antar Variabel

\begin{tabular}{lccc}
\hline \multicolumn{1}{c}{ Pengaruh Variabel } & $\mathbf{R}$ & Sig. & Keterangan \\
\hline Hardiness terhadap kinerja & 0,690 & 0,000 & Signifikan \\
\hline $\begin{array}{l}\text { Kepemimpinan transformational } \\
\text { terhadap kinerja }\end{array}$ & 0,114 & 0,166 & Signifikan \\
\hline
\end{tabular}

Berdasarkan tabel di atas diketahui nilai signifikansi antara variabel kepribadian hardiness (X1) dengan kinerja $(\mathrm{Y})$ sebesar $0,000<0,05$, yang berarti terdapat korelasi yang signifikan antara variabel kepribadian hardiness dengan variabel kinerja. Selanjutnya, korelasi antara variabel kepemimpinan transformational (X2) dengan kinerja $(Y)$ memiliki nilai signifikan sebesar $0,166>0,05$, artinya tidak terdapat korelasi yang signifikan antara variabel kepemimpinan transformational dengan variabel kinerja.

Table 5. Deskripsi Uji regresi berganda

\begin{tabular}{lccccc}
\hline Variabel & $\mathbf{r}$ & $\mathbf{r}^{2}$ & $\mathbf{F}$ & Sig \\
\hline $\begin{array}{l}\text { Hardiness dan kepemimpinan } \\
\text { transformational terhadap kinerja }\end{array}$ & 0,705 & 0,497 & 72,511 & 0,000 \\
\hline
\end{tabular}

Berdasarkan tabel diatas diketahui nilai koefisien korelasi (r) yaitu sebesar 0,705 yang menunjukkan bahwa variabel kepribadian hardiness dan kepemimpinan transformational secara simultan berkorelasi positif. Sedangkan nilai koefisien determinan $\left(\mathrm{r}^{2}\right)$ sebesar 0,497 artinya presentase sumbungan pengaruh variabel kepribadian hardiness (X1) dan kepemimpinan transformational (X2) terhadap kinerja 
(Y) secara simultan adalah sebesar 49\% dan 51\% dipengaruhi oleh variabel lain yang tidak diteliti dalam penelitian ini.

Berikutnya untuk mengetahui secara bersama-sama variabel independen berpengaruh signifikan terhadap variabel dependen maka harus membandingkan $\mathrm{F}$ hitung dengan $\mathrm{F}$ tabel. Dikatakan ada pengaruh jika nilai $\mathrm{F}$ hitung $>\mathrm{F}$ tabel. Dalam penelitian ini diketahui nilai $\mathrm{F}$ hitung sebesar 72,511 dan nilai $\mathrm{F}$ tabel sebesar 3,06. Artinya nilai $\mathrm{F}$ hitung 72,511 > F tabel 3,06 dengan taraf signifikansi $(\mathrm{p})=0,000$ oleh sebab itu dapat dinyatakan bahwa variabel hardiness dan kepemimpinan transformational secara simultan (bersama-sama) berpengaruh terhadap kinerja. Selanjutnya kontribusi antar variabel terhadap kinerja, diketahui presentase sebesar $51,4 \%$ untuk pengaruh kepribadian hardiness terhadap kinerja, dan kepemimpinan transformational sebesar -I,76\%. Dengan demikian dapat disimpulkan bahwa dalam penelitian ini kepribadian hardiness memiliki kontribusi yang lebih tinggi terhadap kinerja dibandingkan kepemimpinan transformational yang tidak memiliki pengaruh terhadap kinerja.

\section{DISKUSI}

Dari hasil penelitian yang telah dilakukan, diketahui bahwa terdapat pengaruh yang signifikan dari kepribadian hardiness dan kepemimpinan transformational terhadap kinerja dengan nilai koefisien $(r)$ sebesar 0,705 dan nilai koefisien $\left(\mathrm{r}^{2}\right)$ determinan 0,497 dengan tingkat signifikan $(P)=0,000$. Artinya kepribadian hardiness dan kepemimpinan transformational memiliki sumbangan pengaruh terhadap kinerja secara simultan atau secara bersama-sama terhadap kinerja yakni sebesar $49 \%$. Hasil penelitian ini membuktikan bahwa hipotesis yang menyatakan terdapat pengaruh kepribadian hardiness dan kepemimpinan transformational terhadap kinerja secara simultan atau secara bersama-sama diterima. Dengan terbuktinya hipotesis ini, maka kepribadian hardiness dan kepemimpinan transformational dapat meningkatkan kinerja karyawan.

Penelitian ini menunjukkan bahwa semakin tinggi kepribadian hardiness dan semakin rendah kepemimpinan transformational maka kinerja semakin tinggi. Dalam hal ini kepribadian hardiness sangat cocok untuk diterapkan pada karyawan PDAM akan tetapi kepemimpianan transformational tidak cocok untuk diterapkan karena karakteristik perusahaan yang berorientasi pada hubungan timbal balik, maka kecenderungan yang diterapkan di PDAM adalah kepemimpinan transaksional, yaitu perilaku pemimpin yang memfokuskan perhatiannya pada transaksi interpersonal antara pemimpin dengan anggota yang melibatkan hubungan pertukaran. Pertukaran tersebut didasarkan pada kesepakatan mengenai klarifikasi sasaran, standar kerja, penugasan kerja, dan penghargaan.

Hasil penelitian ini menunjukkan bahwa faktor internal dan eksternal memberikan peran terhadap pencapaian kinerja karyawan, dalam hal ini kepribadian hardiness sebagai faktor internal dan kepemimpinan transformational sebagai faktor eksternal secara bersama-sama memberikan pengaruh yang signifikan. Salah satu faktor individu yang dapat mempengaruhi kinerja adalah kepribadian tangguh (hardiness), dimana hardiness merupakan pola sikap dan tindakan yang membantu 
mengubah kondisi stres menjadi sebuah peluang untuk berkembang (Cerezo, Galian, Tarroja, Mañalac, \& Ysmael, 2015). Hal ini di dukung oleh penelitian Dodik dan Astuti (2012) menjelaskan bahwa seseorang yang memiliki kepribadian hardiness akan cenderung memiliki penyesuaian diri yang lebih baik terutama pada saat berada pada peristiwa-peristiwa dan kondisi yang beresiko menimbulkan stres di tempat kerja.

Kinerja seseorang merupakan ukuran sejauh mana keberhasilan seseorang dalam melakukan tugas pekerjaannya (Hasibuan, 2016). Kinerja karyawan sering diartikan sebagai pencapaian tugas dimana karyawan dalam bekerja harus sesuai dengan program kerja organisasi untuk menunjukkan tingkat kinerja organisasi dalam mencapai visi, misi dan tujuan organisasi. Kinerja karyawan dapat dijadikan sebagai bahan evaluasi untuk perusahaan. Kinerja memiliki porsi penting dalam organisasi, karena keberhasilan dalam melakukan pekerjaan sangat ditentukan oleh kinerja dan kinerja berkaitan dengan seberapa baik seseorang dalam melakukan tugasnya.

Banyaknya tahapan yang harus dilalui serta situasi yang menekan menyebabkan stres dan banyak hal yang tidak dapat diprediksi ketika dalam menjalankan pekerjaan sehingga membutuhkan dukungan kepribadian hardiness yang mampu menetralisir stress dengan melibatkan kemampuan untuk mengubah secara persepsi dan perilaku penyebab stres yang negatif ke dalam tantangan positif. Kepribadian hardiness merupakan kepribadian yang terbentuk dari lingkungan dan sebagai cara individu untuk menyesuaikan situasi yang penuh tekanan. Individu yang memiliki sifat tahan banting cenderung memandang situasi stres dan pengalaman yang tidak menyenangkan sebagai aspek alami kehidupan. Orang yang memiliki kepribadian hardiness merasa lebih berkomitmen terhadap pekerjaan dan kehidupan dan percaya pada kemampuan mereka untuk melakukan kontrol atas kehidupan dan mengevaluasi situasi yang penuh tekanan sebagai peluang potensial untuk perubahan. Hasil di atas sesuai dengan penelitian Olivia (2014) yang menyatakan bahwa kepribadian hardiness mempengaruhi kinerja pada karyawan.

Kepribadian hardiness didasari oleh tiga sifat kepribadian yaitu kontrol, komitmen dan tantangan. kontrol adalah kayakinan individu bahwa dirinya dapat mempengaruhi peristiwa-peristiwa yang terjadi atas dirinya. Komitmen merupakan keterlibatan dengan orang lain maupun dengan instansi, sehingga tidak mudah menyerah ketika mendapatkan tekanan maupun perubahan-perubahan yang terjadi di instansi. Individu yang memiliki keyakinan bahwa perubahan merupakan suatu yang biasa terjadi dalam kehidupan sehingga perubahan ini dipandang bukan sebagai suatu ancaman pada keamanan melainkan suatu kesempatan untuk lebih berkembang dan tumbuh. Kepribadian hardiness akan bertindak sebagai penyeimbang atau penyangga dampak negatif dari perubahan akibat dari situasi yang tidak menyenangkan dan membawa pengaruh positif terhadap kehidupan individu. Penelitian lain yang mendukung temuan di atas adalah hasil penelitian dari Temaja \& Utama (2016) yang menyatakan bahwa Kepribadian Hardiness berpengaruh pada Kinerja.

Kepribadian hardiness yang tinggi pada karyawan akan memperlihatkan kinerja yang baik, mampu memimpin bawahannya dan memiliki kesehatan yang kuat meskipun sering berada pada situasi yang memiliki stressor yang tinggi serta akan selalu puas dengan hasil dari pekerjaannya dan lebih bertanggung jawab. Kepribadian hardiness merupakan ketahanan psikologis yang dapat membantu dalam mengelola 
stres yang dialami. Ketika seorang karyawan mampu untuk mengelola stres kerja maka kinerja karyawan akan meningkat dan mencapai kinerja yang baik. Hal ini sesuai dengan penelitian yang dilakukan oleh Habibah (2009), menyatakan bahwa hardiness yang tinggi terutama pada komitmen merupakan predictor yang kuat dari tingkat stress yang rendah.

Stres kerja yang terjadi pada karyawan memiliki potensi dalam menurunkan kinerja karyawan, oleh karena itu kemampuan untuk melawan stres sangat dibutuhkan oleh setiap individu dalam bekerja. Penelitian tersebut juga sejalan dengan penelitian yang dilakukan oleh Judkins (2001), menyebutkan bahwa tingkat stress rendah jika hardiness tinggi. Ketika seorang karyawan memiliki kepribadian hardiness yang tinggi dan mampu menghadapi atau melawan stres dengan cara mengubah stressor negative menjadi sebuah tantangan yang positif maka karyawan tersebut akan terhindar dari stres sehingga dapat meningkatkan kemampuan dalam mencapai kinerja yang baik. Individu yang memiliki kepribadian hardiness yang tinggi cenderung memiliki kemampuan dalam melawan stress, karena mereka percaya dapat mengontrol dan mempengaruhi kejadian-kejadian dalam hidup. Mereka akan berkomitmen secara mendalam terhadap pekerjaan dan memandang suatu perubahan sebagai suatu kesempatan untuk menuju suatu perkembangan dan pertumbuhan.

Kepemimpinan Transformational dalam penelitian ini secara parsial memberikan pengaruh negatif yang signifikan terhadap kinerja karyawan. Dalam hal ini kepemimpinan Transformational tidak cocok untuk diterapkan pada karyawan PDAM Kota Malang. Sesuai dengan pendapat Robins \& Judge (2015), menyatakan bahwa kepemimpinan transformational adalah pemimpin yang menginspirasi para pengikutnya untuk menyampaikan kepentingan pribadi mereka demi kebaikan organisasi dan mereka mampu memiliki pengaruh yang luar biasa pada diri pengikutnya. Mereka menaruh perhatian terhadap kebutuhan pengembangan diri para pengikutnya, mengubah kesadaran para pengikut atas isu-isu yang ada dengan cara membantu orang lain memandang masalah lama dengan cara baru, serta mampu menyenangkan hati dan menginspirasi para pengikutnya untuk bekerja keras guna mencapai tujuan bersama.

Gaya kepemimpinan transformational memiliki empat dimensi menurut Pradana (2013) pertama, idealized influence, yang ditandai dengan kuatnya visi dan misi yang menimbulkan rasa hormat, membuat karyawan menjadi lebih optimis dan pentingnya menentukan tujuan serta pimpinan akan membuat karyawan memiliki rasa percaya diri. Kedua, inspirational motivation, mencakup kapasitas seorang pimpinan untuk menjadikan dirinya sebagai panutan bagi karyawan dimana pimpinan menyampaikan tujuan yang jelas dan memberikan contoh yang baik bagi karyawannya. Ketiga, intellectual simulation, merupakan kemampuan pimpinan untuk menghilangkan rasa enggan yang dimiliki karyawan dalam memberikan ide-ide, mendorong karyawan lebih kreatif dan membuat karyawan berfikir dalam menyelesaikan masalah yang ada. Keempat, individual consideration, perhatian yang diberikan pemimpin seperti memberikan bimbingan kepada karyawan dengan memberikan perhatian personal dan memberikan perhatian khusus agar karyawan mampu mengembangkan kemampuannya. Kepemimpinan transformational dalam penelitian ini memiliki 
sumbangan signifikan negatif terhadap kinerja karyawan. Sehinga diperoleh sebuah kesimpulan bahwa atasan kurang efektif menerapkan pola kepemimpinan transformational di PDAM Kota Malang.

\section{SIMPULAN DAN IMPLIKASI}

Berdasarkan hasil penelitian ini diketahui bahwa hipotesis pada penelitian ini diterima. Hasil dalam penelitian menunjukkan bahwa terdapat pengaruh kepribadian hardiness dan kepemimpinan transformational secara simultan terhadap kinerja dengan berkontribusi sebesar 49\%. Kepribadian hardiness dalam penelitian ini lebih berkontribusi terhadap kinerja dibandingkan dengan kepemimpinan transformational. Variabel yang memberikan kontribusi paling dominan pada kinerja adalah kepribadian hardiness yaitu sebesar 51,4\%, dan kepemimpinan transformational tidak memberikan kontribusi terhadap kinerja karyawan -1,76\%.

Implikasi dari penelitian ini bisa digunakan oleh pihak perusahaan untuk meningkatkan kinerja karyawan melalui peningkatan kepribadian hardiness. Hal ini bisa dilakukan dengan cara mengamati keberhasilan orang lain, seperti pihak perusahaan mengundang orang-orang yang sukses dibidangnya, memutar video inspiratif, mengundang alumni yang sudah memiliki pengamalan dalam memajukan sebuah perusahaan untuk dijadikan teladan dalam lingkungan perusahaan. Kepemimpinan transaksional disarankan untuk diterapkan karena perilaku pemimpin yang memfokuskan perhatiannya pada transaksi interpersonal antara pemimpin dengan anggota yang melibatkan hubungan pertukaran. Pertukaran tersebut didasarkan pada kesepakatan mengenai klarifikasi sasaran, standar kerja, penugasan kerja, dan penghargaan. Kepemimpinan transaksional dapat meningkatakan kemampuan pemimpin untuk menjadikan dirinya sebagai panutan, membuat karyawan lebih percaya diri, menciptakan kreativitas dan membantu karyawan mengembangkan kemampuannya.

\section{REFERENSI}

Amiruddin, J. H., \& Ambarini, T. K. (2014). Pengaruh hardiness dan coping stress terhadap tingkat stres pada kadet akademi TNI-AL. Jurnal Psikologi Industri dan Organisasi, 3(02), 72-78.

Ayundasari, D. Y., Sudiro, A., \& Irawanto, D. W. (2017). Improving employee performance through work motivation and self-efficacy mediated by job satisfaction. Jurnal Aplikasi Manajemen, 15(4), 587-599.

Ayudhia, R. R., \& Kristiana, I. F. (2016). Hubungan antara hardiness dengan perilaku prososial pada siswa kelas XI SMA. Jurnal Empati, 5(04), 205- 210

Azwar S. (2013). Sikap manusia teori dan pengukurannya.Yogyakarta: Pustaka Pelajar.

Bass dan Ruth. 2009. The Bass Handbook of Leadership: Theory, Research and Managerial Aplication. Fourth Edition. Free Pass New York London Toronto Sidney.

Cerezo, A. G. F., Galian, A. D., Tarroja, M. C. H., Mañalac, G. K. Q., \& Ysmael, M. P. R. (2015). Breaking news: How hardiness moderates the impact of burnout on the psychological well-being of filipino journalists covering disasters and emergencies. Philippine Journal of Psychology, 48(2), 175- 194.

Dodik, A. A., \& Astuti, K. (2012). Hubungan antara kepribadian hardiness dengan stres kerja pada anggota Polri bagian operasional di Polresta Yogyakarta. Insight, 10(1), 37-48. 
Drummond, J. T. (1997). The effects of cognitive hardiness on stress, health, performance, and cardiovascular/neuroendocrine function (No. AFIT-97-097). Air Force Inst Of Tech Wright-Patterson Afb Oh.

Devita, M. (2017). Faktor-faktor yang mempengaruhi kinerja karyawan di restaurant alpha hotel Pekanbaru. Jurnal online mahasiswa (JOM) bidang ilmu sosil dan politik, 4(2), 1-15.

Fiery, B. M. (2008). Contextual influences affecting transformational leadership in northwest virginia multiple nonprofit hospital systems (Doctoral dissertation, University of Phoenix).

Hasibuan, M. S. (2016). Manajemen sumber daya manusia. Jakarta: Bumi Aksara.

Harlina Nurtjahjanti, I. Z. (2011). Hubungan kepribadian hardiness dengan optimisme pada calon tenaga kerja Indonesia (CTKI) wanita di BLKLN disnakertrans Jawa Tengah. Jurnal Psikologi Undip Vol. 10, No. 2, 126- 132.

Helmi, A. F., \& Arisudana, I. (2009). Kepemimpinan transformasional, kepercayaan dan berbagi pengetahuan dalam organisasi. Jurnal Psikologi, 36(2), 95-105.

Hutomo, I. S. (2014). Kepribadian tangguh (Hardiness) pada guru sekolah luar biasa B dan C. Universitas Muhammadiyah Surakarta.

Jannah, N. (2018). Hubungan Antara Hardiness Dengan Resiliensi Pada Narapidana Di Lembaga Pemasyarakatan Klas Ii A Perempuan Malang (Doctoral dissertation, University of Muhammadiyah Malang).

Jimenez, B. M., Munoz, A. R., Hernandez, E. G., \& Blanco, L, M. (2014). Development and validation of the occupational hardiness questionnaire. Psichotema, 26, (2), 207-214.

Kadarusman,D. (2012). Natural intelligence leadership: Cara pandang baru terhadap Kecerdasa dan karakter kepemimpinan. Jakarta: Raih Asa Sukses.

Kalantar, J., Khedri, L., Nikbakht, A., \& Motvalian, M. (2013). Effect of psychological hardiness training on mental health of students. International Journal of Academic Research in Business and Social Sciences, 3(3), 68-73.

Kharis, I. (2015). Pengaruh gaya kepemimpinan transformasional terhadap kinerja karyawan dengan motivasi kerja sebagai variabel intervening (studi pada karyawan bank jatim cabang malang). Jurnal Administrasi Bisnis, 20(1).

King, L. A., King, D. W., Keane, T. M., Faribank, J. F., \& Adams, G. A. (1998). Resiliencerecovery factors in posttraumatic stress disorder among female and male Vietnam veterans: Hardiness, postwar social support and additional stressful life events. Journal of Personality and Social Psychology, 74(2), 420-434.

Kobasa, S. C. (1982). Hardiness and health: A prospective study. Journal of personality and social psychology. 42/1: 162-177.

Kobasa, S. C. (1979). Stressful life events, personality, and health: an inquiry into hardiness. Journal of personality and social psychology, 37(1), 1.

Kreitner, R., \& Kinicki, A. (2005). Perilaku Organisasi (5 ed., Vol. 2). (E. Suandy, Penerj.) Jakarta: Salemba Emp

Maddi, S. (2002). The story of hardiness: twenty years of theorizing, research and practice. consulting psychology journal , 54, 173-185.

Maddi, S. (2013). Personal hardiness as the basis for resilience. In Hardiness (pp. 7-17). Springer, Dordrecht.

Mangkunegara, A. P. (2000), Manajemen sumber daya manusia perusahaan, Bandung: PT. Remaja Rosdakarya.

Mangkunegara, Anwar Prabu.(2006) Evaluasi kinerja sumber daya manusia. Edisi Kedua, Bandung: PT Refika Aditama. 
Mahdavi, A., Nikmanesh, E., Aghael, M., Kamran, F., Tavakoli, Z. Z., \& Seddigh, F. K. (2015). Predicting the level of job satisfaction based on hardiness and its components among nurses with tension headache. Journal of medicine and life, 8(4), 93-96. Retrieved from https://www.ncbi.nlm.nih.gov/pmc/a rticles/PMC5319299/.

Mathis Robert, L., Jackson John H., (2009). Human resource management (Terjemahan) Buku 2, Edisi Kesembilan, Jakarta.: Salemba Empat,

Menon, P., \& Yogeswarie. (2015). Sociability, hardiness and resilience in mothers of differently able children. International Journal of Scientific Research, 4(2277), 533-535.

Mondiani, T. (2012). Pengaruh kepemimpinan transformasional dan kompensasi terhadap kinerja karyawan PT. PLN (PERSERO) UPJ Semarang. Jurnal Administrasi Bisnis, 1(1).

Moreno-Jiménez, B., Rodríguez-Muñoz, A., Hernández, E. G., \& Blanco, L. M. (2014). Development and validation of the occupational hardiness questionnaire. Psicothema, 26(2), 207-214.

Mitchell, Terrence R. (1978). People in organization. Tokyo: McGraw Hill

Muchtar, M. (2017). The influence of motivation and work environment on the performance of employees. Sinergi: Jurnal Ilmiah Ilmu Manajemen, 6(2).

Murtiningsih, M. (2017). Pengaruh gaya kepemimpinan transformasional pada kinerja perawat rumah sakit islam siti aisyah Madiun. Jurnal Manajemen Dayasaing, 17(2), 54-66.

Nabi, N., Islam, M., Dip, T. M., \& Hassain, A. A. (2017). Impact of motivation on employee performances: a case study of Karmasangsthan bank Limited, Bangladesh. International Journal of Business and Management, 5(4), 57-78.

Nawawi, H. (2003). Kepemimpinan mengefektifkan orgasnisasi. Yogyakarta : Gajah Mada University Press.

Nurtjahjanti, H., \& Ratnaningsih, I. Z. (2011). Hubungan kepribadian hardiness dengan optimisme pada calon tenaga kerja Indonesia (CTKI) wanita di BLKLN DISNAKERTRANS Jawa Tengah. Jurnal Psikologi Undip, 10(2), 126-132.

Olivia, D. O. (2014). Kepribadian hardiness dengan prestasi kerja pada karyawan bank. Jurnal Ilmiah Psikologi Terapan, 2(1), 115-129.

Omollo, P. A., \& Oloko, M. A. (2015). Effect of motivation on employee performance of commercial banks in Kenya: A case study of Kenya Commercial Bank in Migori County. International journal of human resource studies, 5(2), 87-103.

Orabi, T. G. A. (2016). The impact of transformational leadership style on organizational performance: Evidence from Jordan. International Journal of Human Resource Studies, 6(2), 89-102.

Palgunanto, Y., Suparno, S., \& Dwityanto, A. (2010). Kinerja karyawan ditinjau dari gaya kepemimpinan transformasional. Indigenous: Jurnal Ilmiah Psikologi, 12(1).

Parashakti, R. D., Haryadi, A., \& Nashar, M. (2018). Effect of styles and leadership work discipline to employee performance (Case Study of PT. Telecommunication Indonesia Tbk Dki Jakarta). KnE Social Sciences, 3(10).

Rivai, Veithzal. (2003). Kepemimpinan dan perilaku organisasi. Jakarta : PT Raja Grafi ndo

Robbins dan Judge. (2008). Perilaku organisasi, Edisi Duabelas, Penerbit Salemba Empat: Jakarta.

Robert L Mathis \& John H.Jackson. (2001). Evaluasi kinerja, Jakarta: Erlangga.

Rokhman, W. dan Harsono. (2002). Peningkatan pengaruh kepemimpinan transformasional terhadap kepemimpinan transaksional pada komitmen organisasi dan kepuasan bawahan, journal Empirika, Volume 11, Nomor 1, Juni 2002).

Sardjana, E., Sudarmo, S., \& Suharto, D. G. (2019). The effect of remuneration, work discipline, motivation on performance. International Journal of Multicultural and Multireligious Understanding, 5(6), 136-150. 
Sadeghi, A. and Lope Pihie, Z.A. (2012). Transformational leadership and its predictive effects on leadership effectiveness: International Journal Of Business and Social Science, Vol.3, No.7, pp 186-187.

Sedarmayanti. (2001). Manajemen sumber daya manusia dan produktivitas kerja. Bandung: CV. Mandar Maju.

Soleha, L. K., Komara, A. T., \& Sudia, Y. (2012). Pengaruh kepemimpinan, disiplin kerja, dan komunikasi terhadap kinerja pegawai sekretariat komisi penyiaran indonesia daerah provinsi jawa barat. Jurnal Ekonomi, Bisnis \& Entrepreneurship, 6(1), 37-50.

Simanjuntak, P. J. (2005). Manajemen dan evaluasi kerja. Lembaga Penerbit FEUI, Jakarta.

Simamora, Henry. 2006. Manajemen sumber daya manusia, edisi ketiga, Cetakan kedua, Yogyakarta: Penerbitan STIE YKPN.

Sivrikaya, M. H. (2018). The role of psychological hardiness on performance of scissors kick. Journal of Education and Training Studies, 6(n12a), 70-74.

Sugiyono. (2009). Metode penelitian kuantitatif, kualitatif dan R\&D. Bandung: Alfabeta.

Sukomono, R. J. (2009). Training meditasi NSR Natural Stress Reduction. Jakarta: PT. Raja Grafindo Persada.

Sunarsih. (2001). Kepemimpinan transformasional dalam era perubahan organisasi, Jurnal Manajemen dan Bisnis. Vol 5 No.2. Desember 2001:106-116

Sutarto. (2006). Dasar-dasar kepemimpinan administrasi. Yogyakarta : Gajah Mada University Press.

Tampi, B. J. (2014). Pengaruh gaya kepemimpinan dan motivasi terhadap kinerja karyawan pada PT. Bank Negara Indonesia, tbk (regional sales manado). Jurnal Acta Diurna, 3(4).

Temaja, I. P. E. A. W., \& Utama, I. M. K. (2016). Pengaruh profesionalisme, kepribadian hardiness, motivasi dan budaya organisasi pada kinerja auditor di kantor akuntan publik. E-Jurnal Akuntansi, 1711-1739.

Tentama, F. (2015). Peran kepuasan kerja terhadap kinerja pada guru pegawai negeri sipil (pns) di yogyakarta. Journal Psikologi Undip, 14(1), 1-8.

Tarroja, M. C. H. (2015). Anna Gabrielle F. Cerezo Alison D. Galian Maria Caridad H. Tarroja Gianina Kyla Q. Mañalac Ma. Patricia R. Ysmael. Philippine journal of psychology, 48(2), 175-194.

Thoha, Miftah. (2007). Kepemimpinan dalam Manajemen. Jakarta: PT Raja Grafindo Persada.

Tucker, B. A., \& Russell, R. F. (2004). The influence of the transformational leader. Journal of Leadership \& Organizational Studies, 10(4), 103-111.

Turang, R. C. (2015). Influence of leadership style, motivation, and work discipline on employee performance in Pt. Dayana Cipta. Jurnal Berkala Ilmiah Efisiensi, 15(4).

Wirawan. (2009). Evaluasi kinerja sumber daya manusia. Jakarta: Salemba Empat

Westman, M. (1990). The relationship between stress and performance: The moderating effect of hardiness. Human performance, 3(3), 141-155.

Yukl, G.A. 1989. "Managerial Leadership: A review of theory and research". Journal of manajement, 15, 251-289. 